DALAT UNIVERSITY JOURNAL OF SCIENCE Volume 11, Issue 4, $2021 \quad 76-97$

\title{
COPPER HEXACYANOFERRATE (II): SYNTHESIS, CHARACTERIZATION, AND CESIUM, STRONTIUM ADSORBENT APPLICATION
}

\section{Nguyen Dinh Trung ${ }^{a, b}$, Le Vu Tram Anh ${ }^{a, b}$, Truong Dong Phuong ${ }^{a}$, Kieu Thi Dan Thy ${ }^{a}$, Nguyen Tran Thuy Hong ${ }^{\mathrm{a}}$, Ning Ping ${ }^{\mathrm{c}}$, Duong Thi Huong Giangd, Ho Kim Dan ${ }^{\text {e, * }}$}

\author{
${ }^{a}$ Center for Analysis and Testing, Dalat University, Lam Dong, Vietnam \\ ${ }^{b}$ Faculty of Chemistry and Environment, Dalat University, Lam Dong, Vietnam \\ ${ }^{c}$ Faculty of Environmental Science and Engineering, Kunming University of Science and Technology, \\ Kunming 650500, Yunnan, China. \\ ${ }^{d}$ Lam Ha High School, Lam Dong, Vietnam \\ ${ }^{e}$ Optical Materials Research Group, Science and Technology Advanced Institute, Van Lang University, \\ Ho Chi Minh City, Vietnam \\ ${ }^{f}$ Faculty of Technology, Van Lang University, Ho Chi Minh City, Vietnam \\ *Corresponding author: Email: trungnd@dlu.edu.vn,hokimdan@vlu.edu.vn
}

\section{Article history}

Received: May $29^{\text {th }}, 2021$

Received in revised form: July $28^{\text {th }}, 2021 \mid$ Accepted: September $29^{\text {th }}, 2021$

Available online: October $29^{\text {th }}, 2021$

\begin{abstract}
Low-cost nanoscale copper hexacyanoferrate (CuHF), a good selective adsorbent for cesium $\left(\mathrm{Cs}^{+}\right)$removal, was prepared using the chemical co-precipitation method. Fourier transform infrared spectroscopy (FTIR), X-ray diffraction (XRD), energy-dispersive $X$-ray spectroscopy (EDS), and high-resolution transmission electron microscopy (HR-TEM) were conducted to determine the CuHF morphology. Copper hexacyanoferrate, $\mathrm{Cu}_{13}\left[\mathrm{Fe}(\mathrm{CN})_{6}\right]_{14 \cdot(}(2 \mathrm{~K}) \cdot 1 \mathrm{HH}_{2} \mathrm{O}$, has a cubic structure (space group $\mathrm{F}-43 \mathrm{~m}$ ) in the range of $10-30 \mathrm{~nm}$ and a Brunauer-Emmett-Teller (BET) surface area of $462.42 \mathrm{~m}^{2} / \mathrm{g}$. The removal of $\mathrm{Cs}^{+}$and $\mathrm{Sr}^{2+}$ is dependent on $\mathrm{pH}$; the maximum adsorption capacity $\left(q_{\max }\right)$ of $\mathrm{CuHF}$ is achieved at a $\mathrm{pH}=6$. From the Langmuir model, $q_{\max }=143.95 \mathrm{mg} / \mathrm{g}$ for $\mathrm{Cs}^{+}$and $79.26 \mathrm{mg} / \mathrm{g}$ for $\mathrm{Sr}^{2+}$, respectively. At high concentrations, $\mathrm{Na}^{+}, \mathrm{Ca}^{2+}$, and $\mathrm{K}^{+}$ions have very little effect on $\mathrm{Cs}^{+}$removal, and $\mathrm{Na}^{+}$and $\mathrm{K}^{+}$ions have a higher affinity for removing $\mathrm{Sr}^{2+}$ than $\mathrm{Ca}^{2+}$ at all concentrations. $\mathrm{CuHF}$ has a high affinity for alkaline cations in the order: $\mathrm{Cs}^{+}>\mathrm{K}^{+}>\mathrm{Na}^{+}>\mathrm{Ca}^{2+}>\mathrm{Sr}^{2+}$, as proposed and discussed.
\end{abstract}

Keywords: Adsorption; Cesium; Copper hexacyanoferrate; Strontium.

DOI: http://dx.doi.org/10.37569/DalatUniversity.11.4.901(2021)

Article type: (peer-reviewed) Full-length research article

Copyright () 2021 The author(s).

Licensing: This article is licensed under a CC BY-NC 4.0 


\section{INTRODUCTION}

The nuclear power industry plays a major role in meeting the increasing energy demand caused by rapid economic development in recent years. Radionuclide elements are generated from the normal operations of nuclear power plants and accidents, such as the Three Mile Island (USA) radiation leak in 1979, the Chernobyl (Ukraine) nuclear disaster in 1986, and the Fukushima Daiichi (Japan) nuclear disaster in 2011 (Koo et al., 2014). During the operation of the Dalat nuclear reactor (Vietnam), radioactive wastewater can be generated from the purification, from cleaning the storage pool, and from water leaks. Nuclear power plant wastewater contains a large amount of soluble and insoluble radioactive compounds and other substances. The radionuclide elements have a long half-life and high fission. They are potentially harmful to humans and the environment (Ma et al., 2011; Singh et al., 2008). Several techniques capable of recovering low-metal radionuclides from high-salt-containing solutions are a challenge (Yasunari et al., 2011). The aim is how to decontaminate and reduce the volume of radioactive wastewater. After that, the concentrated wastewater undergoes a process of conditioning, storage, and disposal. The selective separation and removal of radioactive cesium ions from nuclear wastewater are challenging because of the lack of knowledge of the behavior of ultra-trace cesium and strontium ions, which compete with the high amounts of other monovalent and divalent cations in the solution. Many techniques have been developed over the past fifty years to remove radioactive $\mathrm{Cs}^{+}$and $\mathrm{Sr}^{2+}$ from wastewater. The techniques include co-precipitation, solvent extraction, ion exchange and adsorption processes, solid-phase extraction, and solvent extraction methods involving crown ethers (Todd et al., 2004; Aguila et al., 2016; Williams et al., 2015; Xu et al., 2012; Awual et al., 2014; Avramenko et al., 2011; Nilchi et al., 2011). Despite their advantages, extraction, precipitation, membrane processing, and electrodialysis methods have limitations, such as efficiency depending on solid-liquid extraction, generating aqueous and organic secondary waste, fouling and radiation damage to organic membranes, and high operation and capital costs (Rahman et al., 2011). Ion exchange/sorption methods are the most popular solution for $\mathrm{Cs}^{+}$removal (Işık et al., 2020; Khandaker et al., 2018; Ali et al., 2020; Vipin et al., 2016). The ion exchange/sorption methods have good chemical, thermal, and radiation stability and a wide choice of products, ensuring high selectivity for $\mathrm{Cs}^{+}$removal from radioactive wastewater.

Transition metal hexacyanoferrates are complex substances capable of adsorbing strontium and cesium ions from nuclear wastewater (Ali et al., 2020; Haas, 1993; Vipin et al., 2014; Kido et al., 2017; Kiener et al., 2019). The metal hexacyanoferrates have a unique structure and arrangement of electrons, so they adsorb cesium ions efficiently and selectively. These structures are favorable for the interaction and capture of small hydrated ions, such as $\mathrm{Cs}^{+}, \mathrm{K}^{+}, \mathrm{NH}_{4}{ }^{+}$, while the interaction and capture are hindered for metal ions with a larger hydrated radius, such as $\mathrm{Na}^{+}, \mathrm{Ca}^{2+}$, etc. The recovery of cesium ions from wastewater solutions can occur through precipitation processes on the surface of transition metal hexacyanoferrates or through chemical interactions with them. The cesium ions are then adsorbed by the transition metal hexacyanoferrates (Mimura et al., 1997; Haas, 1993). Both types of transition metal hexacyanoferrates analog and nanoscale particles have distinguished themselves. They are promising substances for 
such applications as degradation of selected toxic PAHs (Shanker et al., 2017), catalytic activity (Ali et al., 2009), and separation of cesium (Yang et al., 2014; Ke et al., 2020).

Nanoscale copper hexacyanoferrates $(\mathrm{CuHF})$ have a cubic structure in which the $\mathrm{Cu}^{2+}$ atom is tetrahedrally coordinated to four $\mathrm{N}$ atoms from $\mathrm{CN}$ ligands. The porous framework of copper hexacyanoferrates remains stable with a system of narrow channels and a small free volume (Avila et al., 2008). Nanoscale CuHF has been used in advanced form, as the nanochemistry of these materials has not yet been explored. However, few publications are available on cesium separation with these complexes.

The preparation and application of transitional metal hexacyanoferrates for removing strontium and cesium from solutions have been investigated over the past 50 years. Many experiments have been reported on maximum adsorption capacity, $\mathrm{pH}$, or time effects; however, the most efficient adsorption procedure is not yet obvious (Ali et al., 2020; Vipin et al., 2014; Haas, 1993; Ayrault et al., 1998). The transition metal hexacyanoferrates have various compositions and structures, so their properties are also very complex. Some papers have discussed the cesium adsorption mechanism by copper hexacyanoferrate materials (Ayrault et al., 1998; Ishizaki et al., 2013), but these reports provide limited information. Some papers only mention an ion-exchange mechanism (Loos-Neskovic et al., 2004; Zong et al., 2017; Vipin et al., 2014).

The morphological differences between copper hexacyanoferrates (CuHF) lead to differences in the physical and chemical properties at the nanoscale. This study aims to introduce a cubic (Fm-3m) nanoscale copper hexacyanoferrate adsorbent prepared by a chemical co-precipitation method that is easy to perform and low in cost. The adsorbent is characterized by X-ray diffraction (XRD), Fourier transform infrared (FTIR) spectroscopy, high-resolution transmission electron microscopy (HR-TEM), energy-dispersive X-ray spectroscopy (EDS), and Brunauer-Emmett-Teller (BET) surface area. The CuHF is evaluated for its cesium and strontium adsorption behavior. The adsorption isotherm, $\mathrm{pH}$, adsorption time effect, and the competition of cesium and strontium ions with other ions are studied. The results show that copper hexacyanoferrate is the most efficient in cesium and strontium recovery.

\section{EXPERIMENTAL DETAILS}

\subsection{Materials}

The high-purity reagents in this study were all prepared from analytical-grade chemicals. Double-distilled water was used to prepare the solutions for all experiments. Stock solutions of $\mathrm{Cs}^{+} 1000 \mathrm{mg} / \mathrm{L}, \quad \mathrm{Sr}^{2+} 1000 \mathrm{mg} / \mathrm{L}, \quad \mathrm{K}_{4}\left[\mathrm{Fe}(\mathrm{CN})_{6}\right] .3 \mathrm{H}_{2} \mathrm{O}$, and $\mathrm{CuSO}_{4} .5 \mathrm{H}_{2} \mathrm{O}$ (Merck, Germany) were used. Stock solutions $(500 \mathrm{mg} / \mathrm{L})$ of potassium $\left(\mathrm{K}^{+}\right)$, sodium $\left(\mathrm{Na}^{+}\right)$, and calcium $\left(\mathrm{Ca}^{2+}\right)$ ions were prepared separately from sodium chloride $(\mathrm{NaCl})$, potassium chloride $(\mathrm{KCl})$ and calcium chloride $\left(\mathrm{CaCl}_{2}\right)$. All solutions were used as competing ions in the $\mathrm{Cs}^{+}$and $\mathrm{Sr}^{2+}$ adsorption experiments. 
Cesium $\left(\mathrm{Cs}^{+}\right)$and strontium $\left(\mathrm{Sr}^{2+}\right)$ working solutions were freshly prepared by diluting $\mathrm{CsCl}$ and $\mathrm{SrCl}_{2} \cdot 6 \mathrm{H}_{2} \mathrm{O}$ with double-distilled water. $\mathrm{HNO}_{3}(0.1-0.5 \mathrm{~N})$ and $\mathrm{NaOH}(0.1-0.5 \mathrm{~N})$ were used to adjust the cesium solution $\mathrm{pH}$ as necessary. The cesium and strontium in the solutions were analyzed before and after the adsorption experiments with a Shimadzu AA-7000 atomic absorption spectrometer (Japan) and a Bruker S2 Picofox total reflection X-ray fluorescence spectrometer (Germany). For safety, stable isotopes of cesium and strontium salts were used in the research.

\subsection{Methods}

\subsubsection{Preparation of $\mathrm{CuHF}$ adsorbent}

The CuHF adsorbent was prepared according to the following procedure. $\mathrm{CuSO}_{4} .5 \mathrm{H}_{2} \mathrm{O}$ was dissolved with vigorous stirring in $750 \mathrm{ml}$ of double-distilled water to obtain concentrations of $0.15 \mathrm{M}$. The reactor beaker was placed in an ultrasonic bath. The beaker was equipped with a drop funnel containing $250 \mathrm{~mL}$ of $\mathrm{K}_{4}\left[\mathrm{Fe}(\mathrm{CN})_{6}\right]$ $(0.05 \mathrm{M})$. The $\mathrm{K}_{4}\left[\mathrm{Fe}(\mathrm{CN})_{6}\right]$ solution was slowly dropped into the reactor beaker, which contained a continuously stirred copper sulfate solution. The temperature was maintained at $40{ }^{\circ} \mathrm{C}$. The adsorbent synthesis process was carried out in an ultrasonic bath (Elma S300H, $1500 \mathrm{~W}-50 \mathrm{~Hz}$ ). After 4 hours of reaction, the chocolate-colored precipitate was collected and rinsed five times with double-distilled water, centrifuged (Universal 320-Germany) at 10,000 rpm, and dried at $60^{\circ} \mathrm{C}$ for $24 \mathrm{~h}$. After drying, the material was finely ground to prepare for further experiments.

\subsubsection{Characterization of $\mathrm{CuHF}$ adsorbent}

The adsorbent was characterized with XRD, FTIR spectroscopy, HR-TEM, EDS, and BET. All experimental measurements were performed at ambient air temperature.

\subsubsection{Batch sorption tests}

To determine the adsorption capacity of cesium by CuHF under the given conditions, we weighed exactly $0.1 \mathrm{~g}$ of copper hexacyanoferrate and placed it in a $250 \mathrm{~mL}$ Erlenmeyer flask that contained $100 \mathrm{~mL}$ of a cesium solution. Cesium solution concentrations of $75,100,120,145,170,200,230$, and $250 \mathrm{mg} / \mathrm{L}$ were used. A similar procedure was used for determining the adsorption capacity of strontium by $\mathrm{CuHF}$, except that $1 \mathrm{~g}$ of copper hexacyanoferrate was used, and the strontium solution concentrations were 40, 100, 150, 200, 250, 300, 400, 450, and $550 \mathrm{mg} / \mathrm{L}$.

The $\mathrm{pH}$ of the solution was not adjusted during the adsorption process. The flask was shaken with an IKA HS 260 basic shaker (USA) at $270 \mathrm{rpm}$ for $24 \mathrm{~h}$. All batch experiment processes were carried out at ambient air temperature $\left(25^{\circ} \mathrm{C}\right)$. The initial $\mathrm{pH}$ of the adsorption experiment solution was adjusted to a defined value with $0.01 \mathrm{~N}$ $\mathrm{HNO}_{3}$ or $\mathrm{NaOH}$ and maintained at a designated $\mathrm{pH}$ value. After $24 \mathrm{~h}$ of the reaction, all samples were centrifuged with a Universal 320 centrifuge (Germany) at 10,000 rpm for 5 minutes and filtered through a $0.22-\mu \mathrm{m}$ membrane filter. The filtrate was analyzed for 
cesium and strontium. All adsorption experiments for evaluating isotherms, $\mathrm{pH}$, and contact time effects followed batch sorption test.

The cesium and strontium adsorption capacities of copper hexacyanoferrate were calculated by the change in the cesium and strontium concentrations before and after the adsorption process. The adsorption capacities of cesium and strontium by the adsorbent are calculated from the following expression:

$$
q_{e}=\frac{\mathrm{V}\left(C_{i}-C_{e}\right)}{\mathrm{B}}
$$

where $\mathrm{q}_{\mathrm{e}}$ is the adsorption capacity of the adsorbent (in $\mathrm{mg} / \mathrm{g}$ of adsorbent), $\mathrm{C}_{\mathrm{i}}$ and $\mathrm{C}_{\mathrm{e}}$ are the cesium or strontium concentrations $(\mathrm{mg} / \mathrm{L})$ before and after the adsorption process, respectively, B is the mass ( $\mathrm{g}$ ) of the adsorbent, and $\mathrm{V}$ is the solution volume $(\mathrm{L})$.

The Langmuir adsorption equation is

$$
q_{e}=\frac{\mathrm{Q}_{\mathrm{m}} \mathrm{bC}_{\mathrm{e}}}{1+\mathrm{bC}_{\mathrm{e}}}
$$

where $\mathrm{q}_{\mathrm{e}}$ is the amount of cesium or strontium ions adsorbed by the materials $(\mathrm{mg} / \mathrm{g})$, $\mathrm{Q}_{\mathrm{m}}$ is the maximum adsorption capacity of cesium or strontium ions, $\mathrm{C}_{\mathrm{e}}$ is the concentration at a point of adsorption $(\mathrm{mg} / \mathrm{L})$, and $b$ is the rate constant between adsorption and desorption.

The Freunlich adsorption equation is

$$
q_{\mathrm{e}}=\mathrm{K}_{f} \mathrm{C}_{\mathrm{e}}^{1 / \mathrm{n}}
$$

where $\mathrm{K}_{f}$ and $\mathrm{n}$ are the adsorption constants on reaching equilibrium.

\subsubsection{Studies of Adsorption}

The effect of $\mathrm{pH}$ on cesium and strontium adsorption was examined in a series of batch sorption experiments that used the same initial concentrations of $\mathrm{Cs}^{+}$ $(140 \mathrm{mg} / \mathrm{L})$ and $\mathrm{Sr}^{2+}(150 \mathrm{mg} / \mathrm{L})$. The $\mathrm{pH}$ was maintained at values of 2.0, 3.0, 4.0, 5.0, $6.0,7.0,8.0$, and 9.0 .

All experiments on cesium and strontium adsorption isotherms were conducted at $25^{\circ} \mathrm{C}$ and $\mathrm{pH}=6$ following the batch adsorption procedure. A series of different initial concentrations of $\mathrm{Cs}^{+}$solutions $\left(75-250 \mathrm{mg} / \mathrm{L}\right.$ ) and $\mathrm{Sr}^{2+}$ solutions (40-550 mg/L) were used for evaluating the isothermal parameters of cesium and strontium adsorption.

The effects of time on cesium and strontium adsorption were examined in a series of batch sorption experiments that used the same initial $\mathrm{Cs}^{+}$concentration $(10 \mathrm{mg} / \mathrm{L})$ and $\mathrm{Sr}^{2+}$ concentration $(40 \mathrm{mg} / \mathrm{L})$ while varying time from 0 to 25 hours. The interference of $\mathrm{Ca}^{2+}, \mathrm{K}^{+}$, and $\mathrm{Na}^{+}$on the $\mathrm{Cs}^{+}$or $\mathrm{Sr}^{2+}$ adsorption was evaluated in batch 
experiments. The experimental method was similar to the batch adsorption method described above. The solutions for these competing adsorption experiments were prepared with the addition of $\mathrm{Ca}^{2+}, \mathrm{K}^{+}$, and $\mathrm{Na}^{+}$solutions into the $\mathrm{Cs}^{+}$or $\mathrm{Sr}^{2+}$ solution. The concentrations of the $\mathrm{Ca}^{2+}, \mathrm{K}^{+}$, and $\mathrm{Na}^{+}$competing all cations ranged from 0 to $120 \mathrm{mg} / \mathrm{L}$.

\section{RESULTS AND DISCUSSION}

\subsection{Characterization of CuHF adsorbent}

Figure 1 shows the FTIR spectrum of the CuHF. The spectrum featured a $v(\mathrm{CN})$ band of $\mathrm{CuHF}$ at $2099.59 \mathrm{~cm}^{-1}$. The CuHF FTIR spectrum is composed of three vibrations within the octahedral unit, $[\mathrm{Fe}(\mathrm{CN}) 6]^{4-}: v(\mathrm{CN}), \delta(\mathrm{Fe}-\mathrm{CN})$, and $v(\mathrm{Fe}-\mathrm{C})$. At the same time, the motions from crystal water, $v(\mathrm{OH})$, and $\delta(\mathrm{HOH})$ are present (Nakamoto, 1986). This relatively high frequency for the $v(\mathrm{CN})$ band in a ferrocyanide suggests a tetrahedral $[\mathrm{Fe}(\mathrm{CN}) 6]^{4-}$ coordination for the copper atom. When the $\mathrm{Cu}$ atom is octahedrally coordinated to $\mathrm{N}$ ends of $\mathrm{CN}$ groups, this vibration is an observed band below $2095 \mathrm{~cm}^{-1}$. Similar evidence obtained from the $\delta(\mathrm{Fe}-\mathrm{CN})$ and $v(\mathrm{Fe}-\mathrm{C})$ frequencies was observed in the bands at $590.92 \mathrm{~cm}^{-1}$ and $472.71 \mathrm{~cm}^{-1}$, respectively.

For this compound, a $\delta(\mathrm{HOH})$ narrowband at $1623.14 \mathrm{~cm}^{-1}$ was observed. In the $v(\mathrm{OH})$ region, two absorption bands at $3609.12 \mathrm{~cm}^{-1}$ and $3452.00 \mathrm{~cm}^{-1}$ appear, ascribed to symmetric and asymmetric $\mathrm{OH}$ stretching, respectively, of coordinated water. This result indicates the existence of one type of crystal binding to water molecules: $\mathrm{CuHF} . \mathrm{xH}_{2} \mathrm{O}$. The FTIR spectrum of this study is also consistent with the research results of Avila et al. (2008).

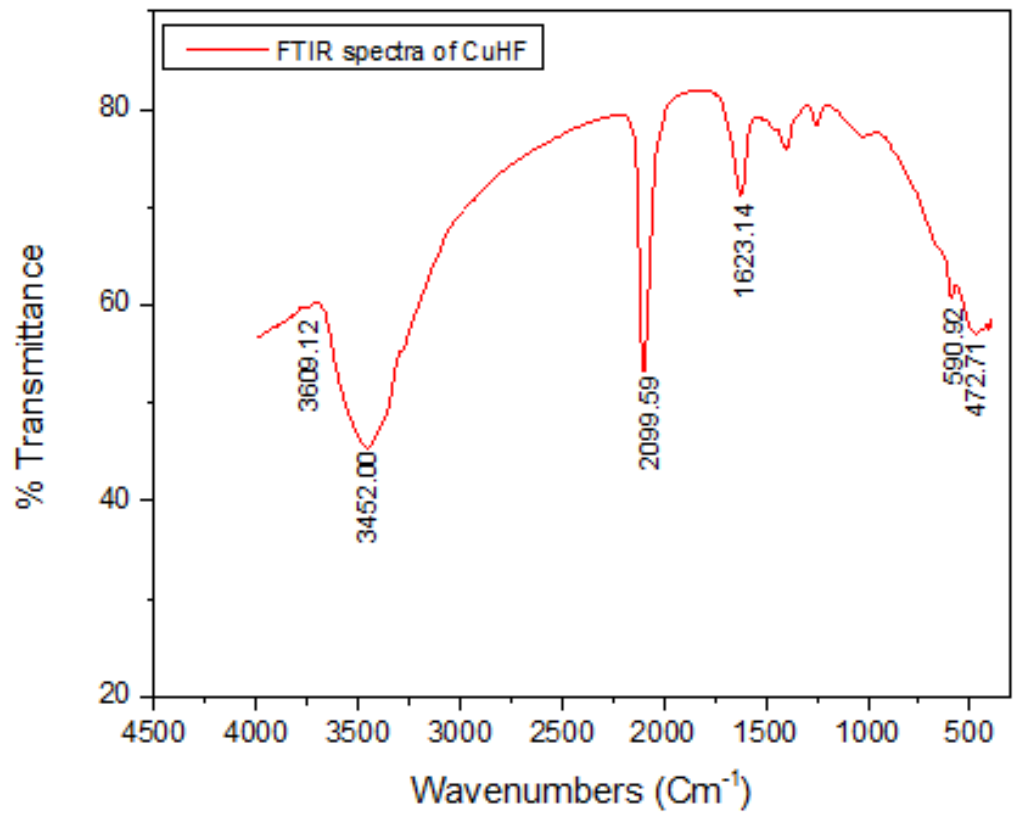

Figure 1. FTIR spectrum of CuHF 
The elemental composition of the complex substance was examined using transmission electron microscopy coupled with energy-dispersive X-ray spectroscopy (EDS). The EDS spectrum of CuHF. $\mathrm{xH}_{2} \mathrm{O}$ is shown in Figure 2.

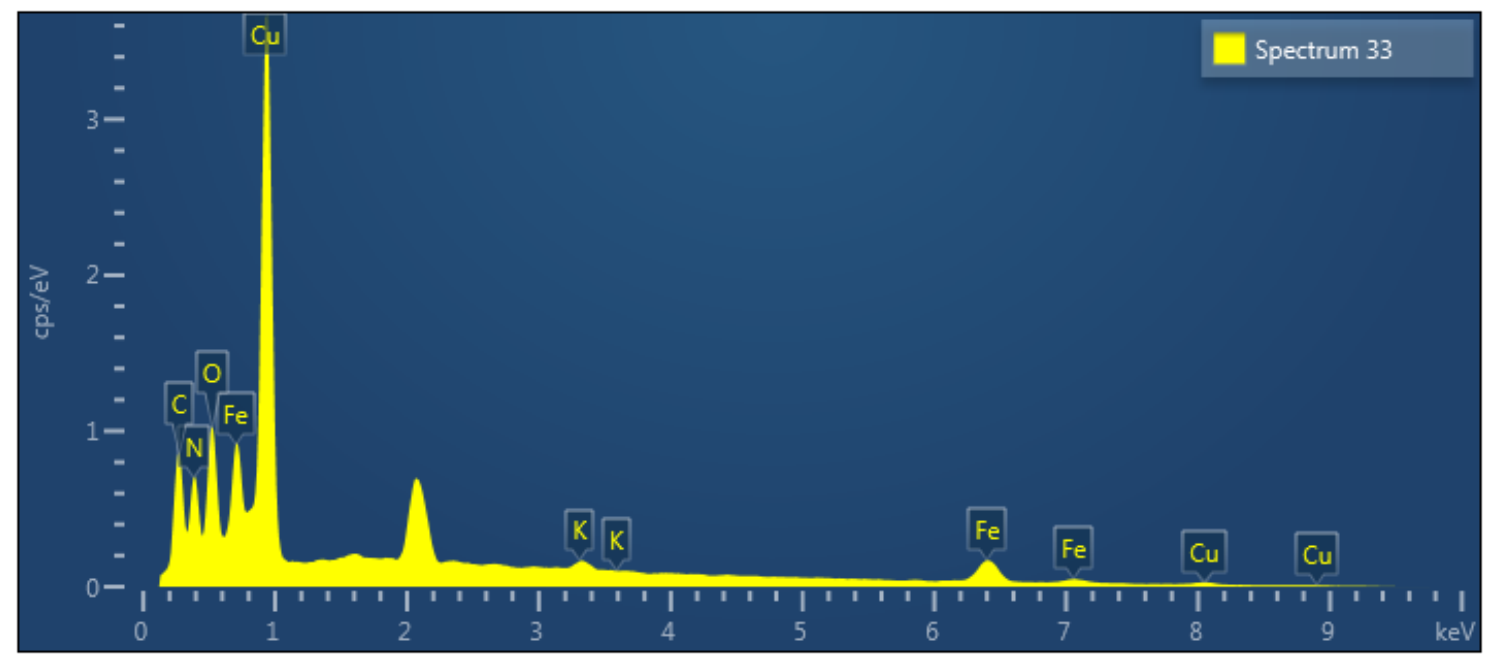

Figure 2. EDS spectrum of CuHF

Table 1. Elemental composition of the complex substance

\begin{tabular}{llll}
\hline Element & Line Type & Weight $(\%)$ & Atomic $(\%)$ \\
\hline $\mathrm{Cu}$ & L series & 22.74 & 7.11 \\
$\mathrm{Fe}$ & L series & 18.71 & 6.64 \\
$\mathrm{C}$ & K series & 24.05 & 39.81 \\
$\mathrm{~N}$ & K series & 28.06 & 39.81 \\
$\mathrm{O}$ & K series & 4.58 & 5.69 \\
$\mathrm{~K}$ & K series & 1.86 & 0.95 \\
\hline
\end{tabular}

The atomic percentages of different elements of the complex substance are given in Table 1, from which it can be deduced that the molecular formula of the copper hexacyanoferrate was $\mathrm{Cu}_{13}\left[\mathrm{Fe}(\mathrm{CN})_{6}\right]_{14} \cdot(2 \mathrm{~K}) \cdot 10 \mathrm{H}_{2} \mathrm{O}$. CuHF exhibits a great variety of compositions and structures. Several compositions may be observed with the same transition metal, depending on the preparation method (Kiener et al., 2019).

Previous papers have reported on synthesized copper hexacyanoferrate with the formula $\mathrm{K}_{1.97} \mathrm{Cu}_{1.00}^{\mathrm{II}_{1.00}} \mathrm{Fe}(\mathrm{CN})_{6}$ (Loos-Neskovic et al., 2004), $\mathrm{K}_{2 / 3} \mathrm{Cu}\left[\mathrm{Fe}(\mathrm{CN})_{6}\right]_{2 / 3} \cdot \mathrm{zH} 2 \mathrm{O}$ (Takahashi et al., 2016), and $\mathrm{K}_{2} \mathrm{CuFe}(\mathrm{CN})_{6}$ (Wang et al., 2009). In a chemical formula, the indices must be integers such as 1, 2, 3. Expressing the chemical formula as $\mathrm{K}_{1.97} \mathrm{Cu}^{\mathrm{II}}{ }_{1.00} \mathrm{Fe}(\mathrm{CN})_{6}$ causes misunderstanding. If the complex molecules contain potassium in the $\mathrm{K}_{2} \mathrm{CuFe}(\mathrm{CN})_{6}$ framework, this component may be water-soluble (Vincent et al., 2015). 
The adsorbent was prepared according to the following chemical equations:

$$
\begin{aligned}
& 2 \mathrm{CuSO}_{4} \text { (redundant) }+\mathrm{K}_{4}\left[\mathrm{Fe}(\mathrm{CN})_{6}\right] \rightarrow \mathrm{Cu}_{2}\left[\mathrm{Fe}(\mathrm{CN})_{6}\right]+2 \mathrm{~K}_{2} \mathrm{SO}_{4} \\
& \mathrm{CuSO}_{4}+\mathrm{K}_{4}\left[\mathrm{Fe}(\mathrm{CN})_{6}\right] \text { (redundant) } \rightarrow \mathrm{K}_{2} \mathrm{Cu}\left[\mathrm{Fe}(\mathrm{CN})_{6}\right]+\mathrm{K}_{2} \mathrm{SO}_{4}
\end{aligned}
$$

The $\mathrm{K}_{2} \mathrm{Cu}\left[\mathrm{Fe}(\mathrm{CN})_{6}\right]$ dissolves in the solution (Vincent et al., 2015), so it was removed after the chocolate-colored precipitate was rinsed with double-distilled water five times. Thus, the $\mathrm{K}^{+}$ions in the adsorbent (Figure 2) may be the ions that were adsorbed by the adsorbent that had just been prepared.

The morphology of the complex substance (CuHF) is shown in Figure 3. The bulk structures of the adsorbents can be seen in the HR-TEM image, and they have precise geometric shapes. The TEM micrographs of the complex substance show a zeolitic structure in the range of $10-30 \mathrm{~nm}$.

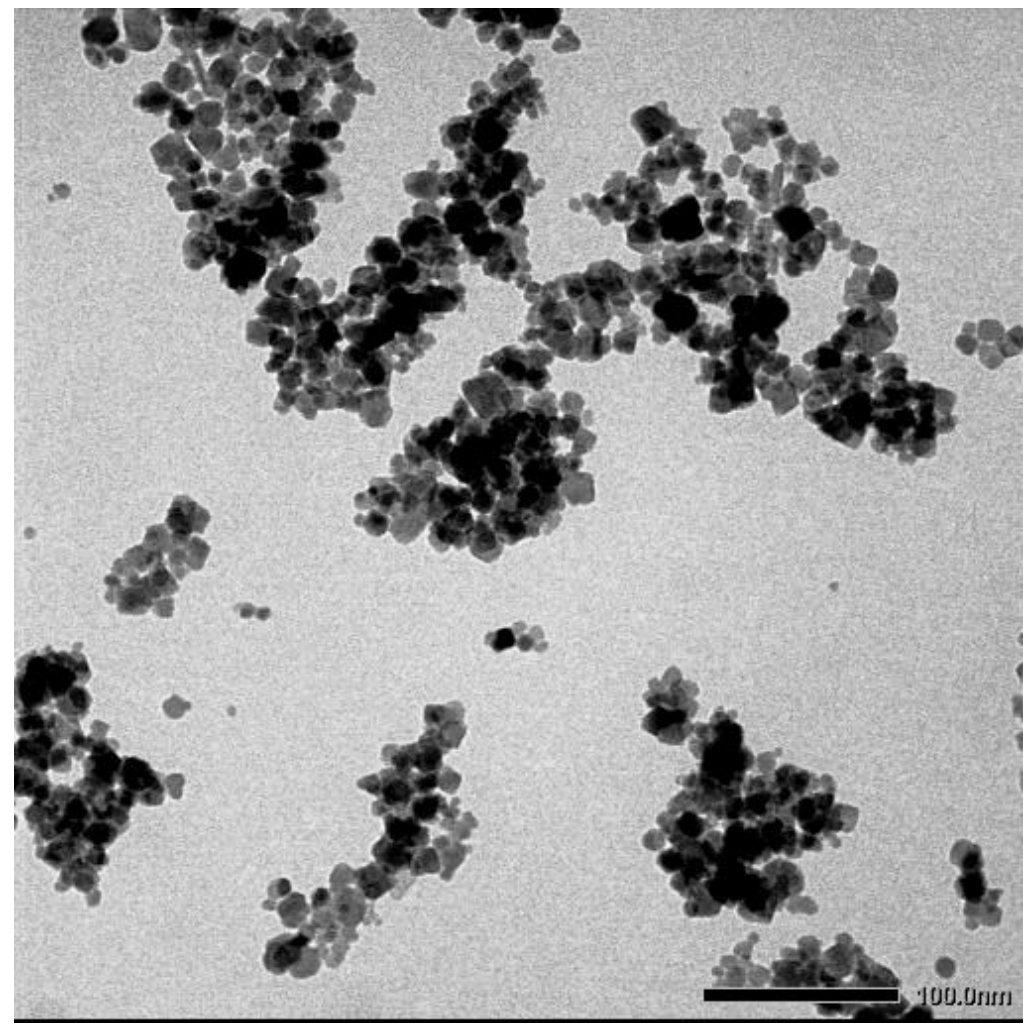

Figure 3(a). HR-TEM image of CuHF 


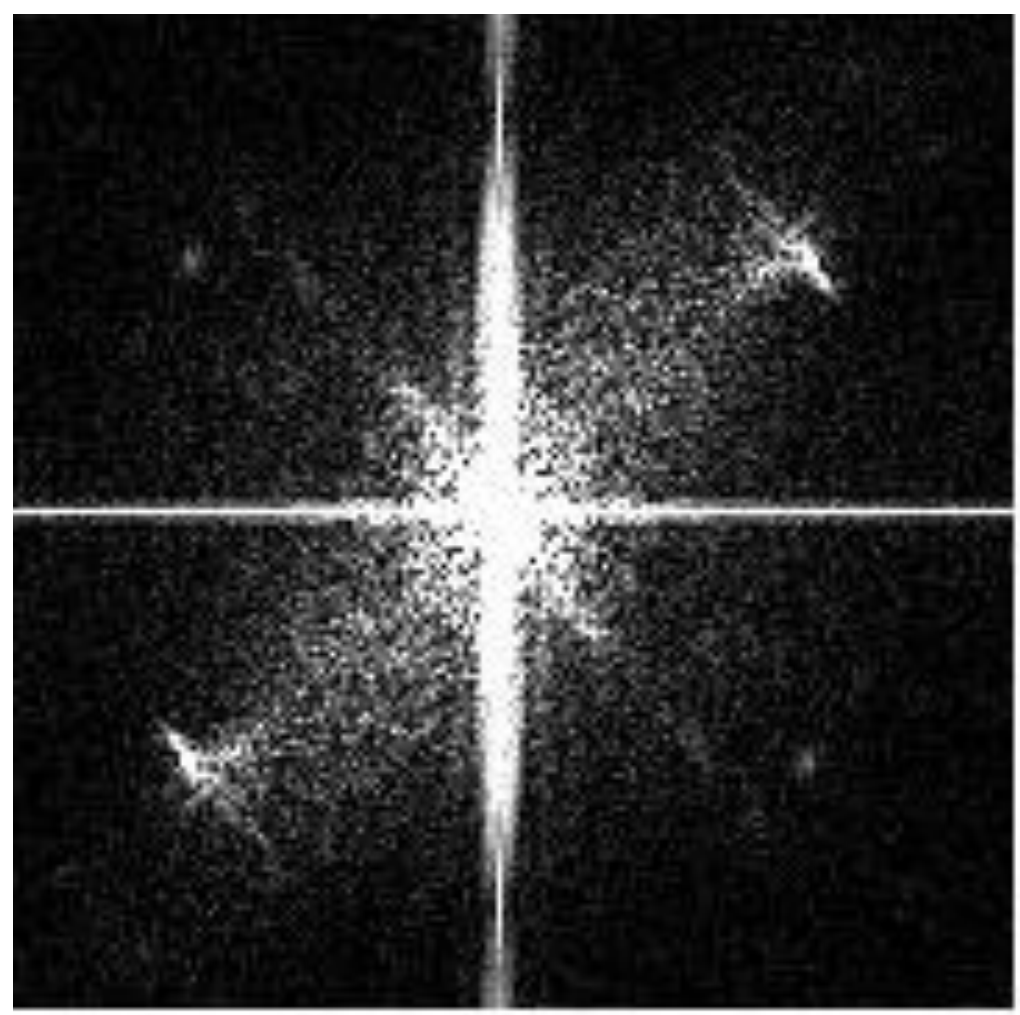

Figure 3(b). HR-TEM image of one unit cell of CuHF

The evidence from the XRD data was analyzed by FullProf Suite software with standard 101038.cif (Murray-Rust, 2021) to identify the crystal structure of CuHF that had just been prepared. The solid red circles are the XRD diagram of $\mathrm{Cu}_{2} \mathrm{Fe}(\mathrm{CN})_{6}$, and the blue line is the standard diagram.

$$
\text { Cycle: } 100 \text { Chi2: 4.50 cu2FecN6.dat }
$$

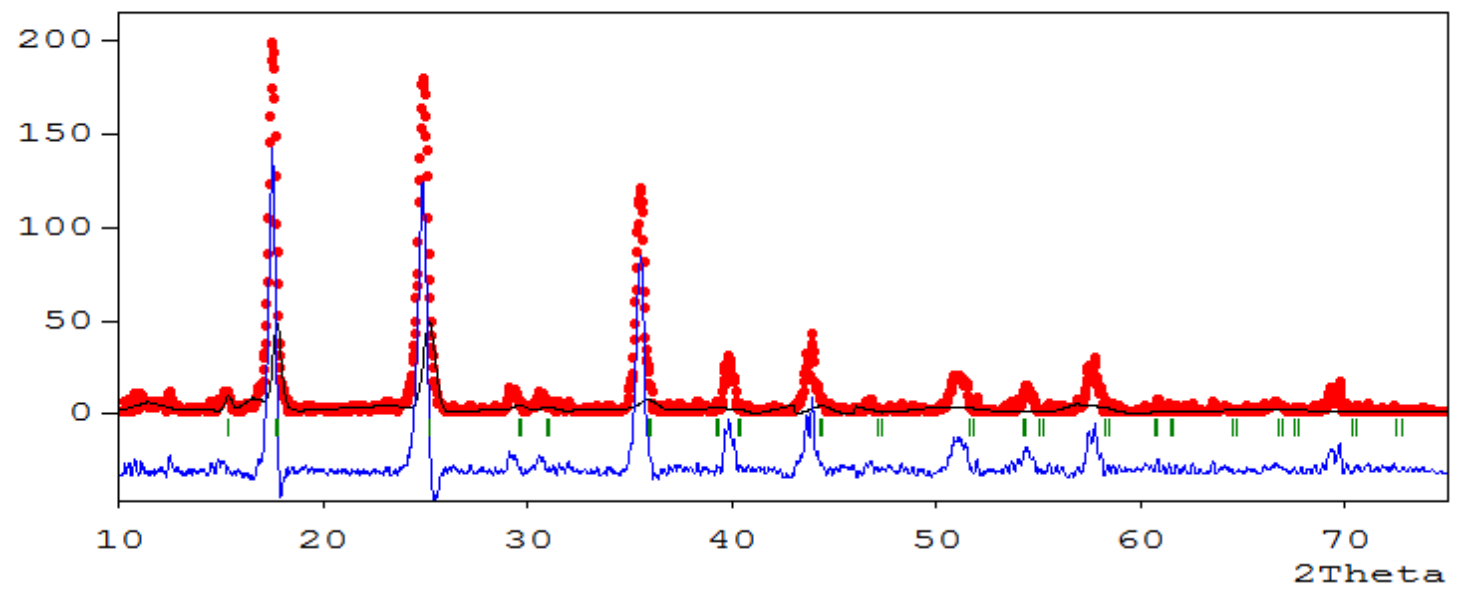

Figure 4. XRD diagram of CuHF compared to the standard

Note: $\mathrm{Cu}_{2} \mathrm{Fe}(\mathrm{CN})_{6}$ is shown as solid red circles; the standard is shown as a blue line. 
The Miller indices [h, k, l] of the CuHF Bravais lattice and crystal system were calculated by Rietveld refinement using FullProf Suite software. The results indicate that the sample has the same main copper hexacyanoferrate peak as the standard. The main cubic crystal has Miller indices d[h,k,l]:

$$
d[1,1,1]=\frac{a}{\sqrt{3}}=5.01, d[2,0,0]=\frac{a}{2}=3.04 \text {, and } d[2,2,0]=\frac{a}{2 \sqrt{2}}=3.01 \ldots \text { The }
$$

main cubic crystal is combined with eight subcubics (Sun et al., 2020).

The morphology of copper hexacyanoferrate was further characterized by highresolution transmission electron microscopy (HR-TEM). The picture of one unit cell (in Figure $3 b$ ) and the elemental composition of the complex substance (Table 1) are enough to confirm the cubic structure of CuHF (space group F-43m). The crystal structure of one unit cell drawn with VESTA software is presented in Figure 5.
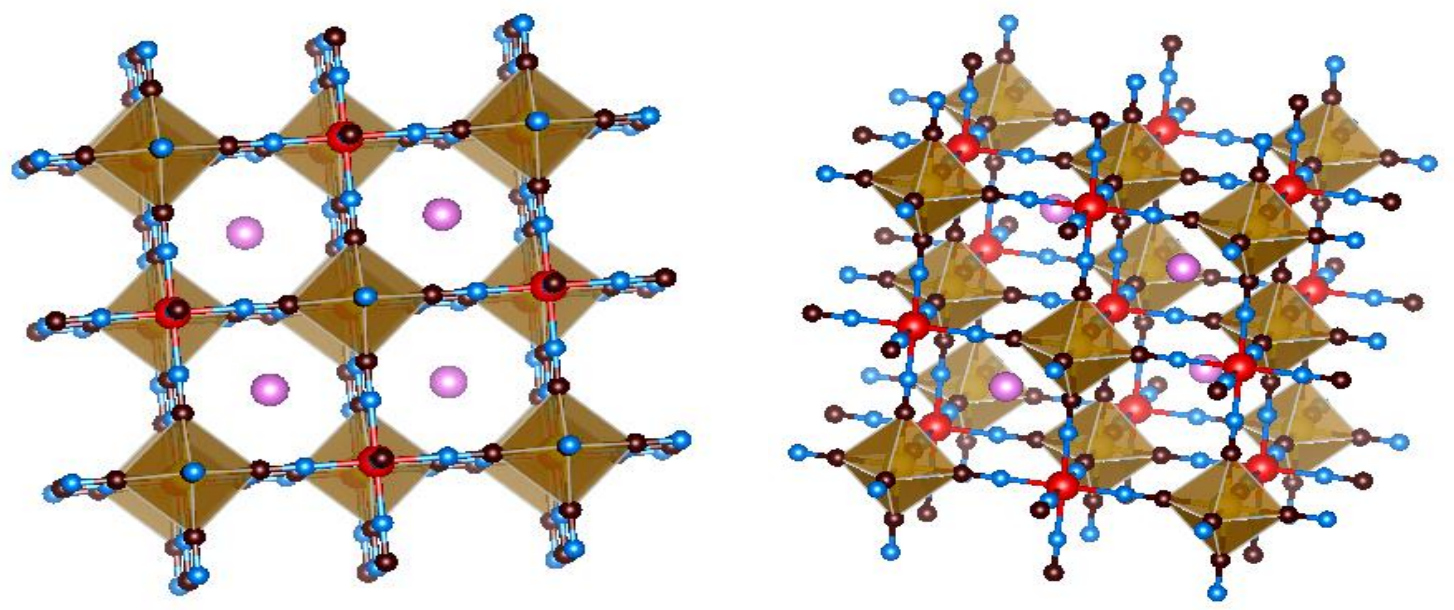

Figure 5. A unit cell of $\left.\mathrm{Cu}_{13}\left[\mathrm{Fe}(\mathrm{CN})_{6}\right]\right]_{14 .}(2 \mathrm{~K}) \cdot \mathrm{10H}_{2} \mathrm{O}$

Note: blue $(\mathrm{N})$, black $(\mathrm{C})$, red $(\mathrm{Cu})$, yellow $(\mathrm{Fe})$, pink $\left(\mathrm{H}_{2} \mathrm{O}\right.$ or $\left.\mathrm{Cu}^{2+}, \mathrm{K}^{+}\right)$.

Table 2. The physicochemical characteristics of CuHF

\begin{tabular}{ll}
\hline BET surface area & $462.42 \mathrm{~m}^{2} / \mathrm{g}$ \\
\hline Pore volume & $0.07 \mathrm{~cm}^{3} / \mathrm{g}$ \\
\hline D-H adsorption average pore width & $3.12 \mathrm{~nm}$ \\
\hline
\end{tabular}

Copper hexacyanoferrate has a cubic zeolitic structure in the range of 10-30 nm with cavities that can host $\mathrm{K}^{+}$ions and water molecules (Loos-Neskovic et al., 2004). $\mathrm{CuHF}$ is suitable to adsorb cesium; it can be prepared repeatedly and maintains constant composition. The BET surface area is $462.42 \mathrm{~m}^{2} / \mathrm{g}$ (Table 2). The complex substance is an adsorbent for further experiments. 


\subsection{The effect of $\mathrm{pH}$ on adsorption}

The adsorption of $\mathrm{Cs}^{+}$and $\mathrm{Sr}^{2+}$ onto $\mathrm{CuHF}$ as a function of the initial concentration $\mathrm{pH}$ is shown in Figure 6. The removal of $\mathrm{Cs}^{+}$and $\mathrm{Sr}^{2+}$ was dependent on $\mathrm{pH}$, with the most significant adsorption occurring under near-neutral $\mathrm{pH}$.

For cesium (Figure 6a), the maximum adsorption capacity is at $\mathrm{pH}=6$. This result agrees with that of the Loos-Neskovic group ( $\mathrm{pH} 5-8$ ), while the report of Clarke and Wai shows the selective removal of cesium by CuHF from neutral to acidic solutions (Clarke \& Wai, 1998). For strontium (Figure 6b), the maximum adsorption capacities of CuHF range in $\mathrm{pH}$ from 4 to 9 . This result agrees with that of the Vipin group (pH 4-9) (Vipin et al., 2014). Therefore, we chose to do all tests at $\mathrm{pH}=6$ in these experiments.

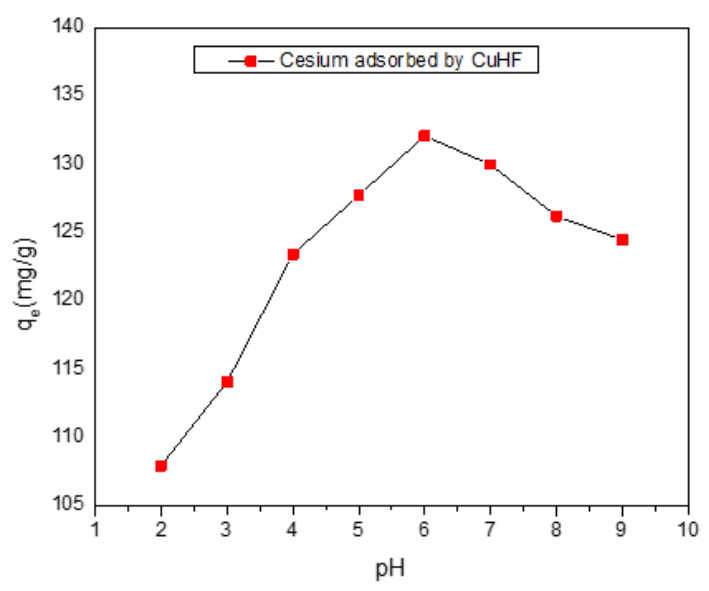

(a)

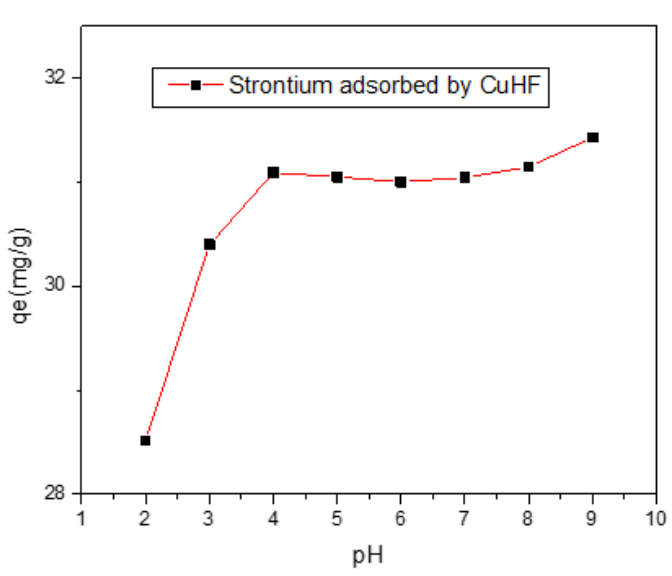

(b)

Figure 6. Cesium and strontium ion adsorption onto $\mathrm{CuHF}$ at various initial $\mathbf{p H}$

Note: (a) Cesium ion adsorption onto $\operatorname{CuHF}\left(1 \mathrm{gL}^{-1}\right)$; (b) Strontium ion adsorption onto CuHF $\left(10 \mathrm{gL}^{-1}\right)$.

\subsection{The adsorption isotherm effect}

For cesium (Table 3 ), the amount of $\mathrm{Cs}^{+}$removed increases significantly with an increase in the initial $\mathrm{Cs}^{+}$concentration because of a stronger dynamic of mass transfer at higher concentrations (Figure 7). However, the adsorption slows slightly when the maximum adsorption capacity is reached above an initial concentration of $170 \mathrm{mg} / \mathrm{L}$ $\mathrm{Cs}^{+}$, after which the $\mathrm{Cs}^{+}$adsorption rate decreases as the initial $\mathrm{Cs}^{+}$concentration increases. When the concentration of $\mathrm{Cs}^{+}$is $200 \mathrm{mg} / \mathrm{L}$, the amount of $\mathrm{Cs}^{+}$adsorption is $142.21 \mathrm{mg} / \mathrm{g}$. When the concentration of $\mathrm{Cs}^{+}$is increased to $250 \mathrm{mg} / \mathrm{L}$, the adsorption capacity of $\mathrm{Cs}^{+}$ions by copper hexacyanoferrate increases slightly. These results are likely due to the higher $\mathrm{Cs}^{+}$concentration, more saturated adsorption sites, and the observed reduced removal efficiency. The highest adsorption capacity of $\mathrm{Cs}^{+}$ions by $\mathrm{CuHF}$ was found to be $144.17 \mathrm{mg} / \mathrm{g}$. 
For strontium (Table 4), the adsorption process occurs strongly when the initial concentration of strontium in solution is high. When the concentration of $\mathrm{Sr}^{2+}$ is $400 \mathrm{mg} / \mathrm{L}$, the amount of $\mathrm{Sr}^{2+}$ adsorption is $39.93 \mathrm{mg} / \mathrm{g}$. When the concentration of $\mathrm{Sr}^{2+}$ is increased to $550 \mathrm{mg} / \mathrm{L}$, the adsorption capacity of $\mathrm{Sr}^{2+}$ ions by $\mathrm{CuHF}$ increases slightly.

Table 3. Cesium ion adsorption onto $\mathrm{CuHF}\left(1 \mathrm{gL}^{-1}\right)$ at various initial cesium concentrations

\begin{tabular}{llllll}
\hline $\begin{array}{l}\text { Cesium concentration } \\
\begin{array}{l}\mathrm{C}_{\mathrm{i}}(\mathrm{mg} / \mathrm{L}) \text { before } \\
\text { adsorption }\end{array}\end{array}$ & $\begin{array}{l}\text { Cesium } \\
\text { concentration } \\
\mathrm{C}_{\mathrm{e}}(\mathrm{mg} / \mathrm{L}) \text { after } \\
\text { adsorption }\end{array}$ & $\begin{array}{l}\text { Mass B of } \\
\text { adsorbent } \\
(\mathrm{g})\end{array}$ & $\begin{array}{l}\text { Solution } \\
\text { volume } \\
\mathrm{V}(\mathrm{L})\end{array}$ & $\begin{array}{l}\text { Adsorption } \\
\text { capacity of } \\
\text { adsorbent } \\
\mathrm{q}_{\mathrm{e}}(\mathrm{mg} / \mathrm{g})\end{array}$ & $\begin{array}{l}\text { Adsorption } \\
\text { capacity of } \\
\text { adsorbent } \\
\mathrm{q}_{\mathrm{e}}(\mathrm{mEq} / \mathrm{g})\end{array}$ \\
\hline 75 & 1.05 & 0.10 & 0.10 & 73.95 & 0.56 \\
100 & 4.29 & 0.10 & 0.10 & 95.71 & 0.72 \\
120 & 5.89 & 0.10 & 0.10 & 114.11 & 0.86 \\
145 & 10.48 & 0.10 & 0.10 & 134.52 & 1.01 \\
170 & 32.17 & 0.10 & 0.10 & 137.83 & 1.04 \\
200 & 67.79 & 0.10 & 0.10 & 142.21 & 1.07 \\
230 & 86.67 & 0.10 & 0.10 & 143.33 & 1.08 \\
250 & 105.83 & 0.10 & 0.10 & 144.17 & 1.08 \\
\hline
\end{tabular}

Table 4. Strontium ion adsorption onto $\mathrm{CuHF}\left(10 \mathrm{gL}^{-1}\right)$ at various initial strontium concentrations

\begin{tabular}{llllll}
\hline $\begin{array}{l}\text { Strontium } \\
\text { concentration } \mathrm{C}_{\mathrm{i}} \\
(\mathrm{mg} / \mathrm{L}) \text { before } \\
\text { adsorption }\end{array}$ & $\begin{array}{l}\text { Strontium } \\
\text { concentration } \\
\mathrm{C}_{\mathrm{e}}(\mathrm{mg} / \mathrm{L}) \text { after } \\
\text { adsorption }\end{array}$ & $\begin{array}{l}\text { Mass B of } \\
\text { adsorbent }\end{array}$ & $\begin{array}{l}\text { Solution } \\
\text { volume } \\
\mathrm{V}(\mathrm{L})\end{array}$ & $\begin{array}{l}\text { Adsorption } \\
\text { capacity of } \\
\text { adsorbent } \\
\mathrm{q}_{\mathrm{e}}(\mathrm{mg} / \mathrm{g})\end{array}$ & $\begin{array}{l}\text { Adsorption } \\
\text { capacity of } \\
\text { adsorbent } \\
\mathrm{q}_{\mathrm{e}}(\mathrm{mEq} / \mathrm{g})\end{array}$ \\
\hline 41.46 & 0.15 & 1 & 0.10 & 4.13 & 0.09 \\
107.39 & 0.59 & 1 & 0.10 & 10.68 & 0.25 \\
147.72 & 0.92 & 1 & 0.10 & 14.68 & 0.34 \\
189.57 & 1.24 & 1 & 0.10 & 18.83 & 0.43 \\
250.59 & 1.95 & 1 & 0.10 & 24.86 & 0.57 \\
313.49 & 3.11 & 1 & 0.10 & 31.04 & 0.72 \\
403.14 & 3.85 & 1 & 0.10 & 39.93 & 0.92 \\
474.11 & 6.71 & 1 & 0.10 & 46.74 & 1.08 \\
561.76 & 8.81 & 1 & 0.10 & 55.29 & 1.28 \\
\hline
\end{tabular}


All experiments were conducted at $25^{\circ} \mathrm{C}$ and $\mathrm{pH}=6$ by following the batch adsorption procedure. The amounts of $\mathrm{Cs}^{+}$and $\mathrm{Sr}^{2+}$ uptake by $\mathrm{CuHF}$ are shown in Figures 7 and 8 . The Langmuir and Freundlich isotherm parameters for the adsorbed $\mathrm{Cs}^{+}$and $\mathrm{Sr}^{2+}$ ions are given in Table 5 .

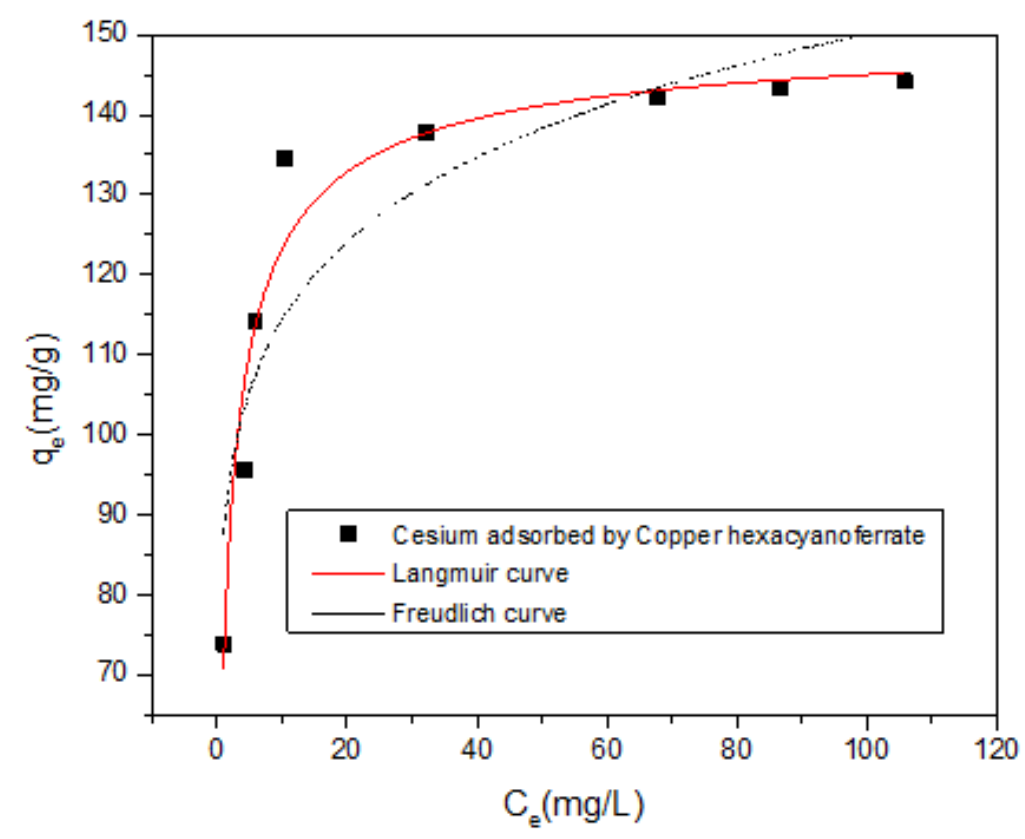

Figure 7. Langmuir and Freundlich isotherms for the adsorption of $\mathrm{Cs}^{+}$on $\mathrm{CuHF}$

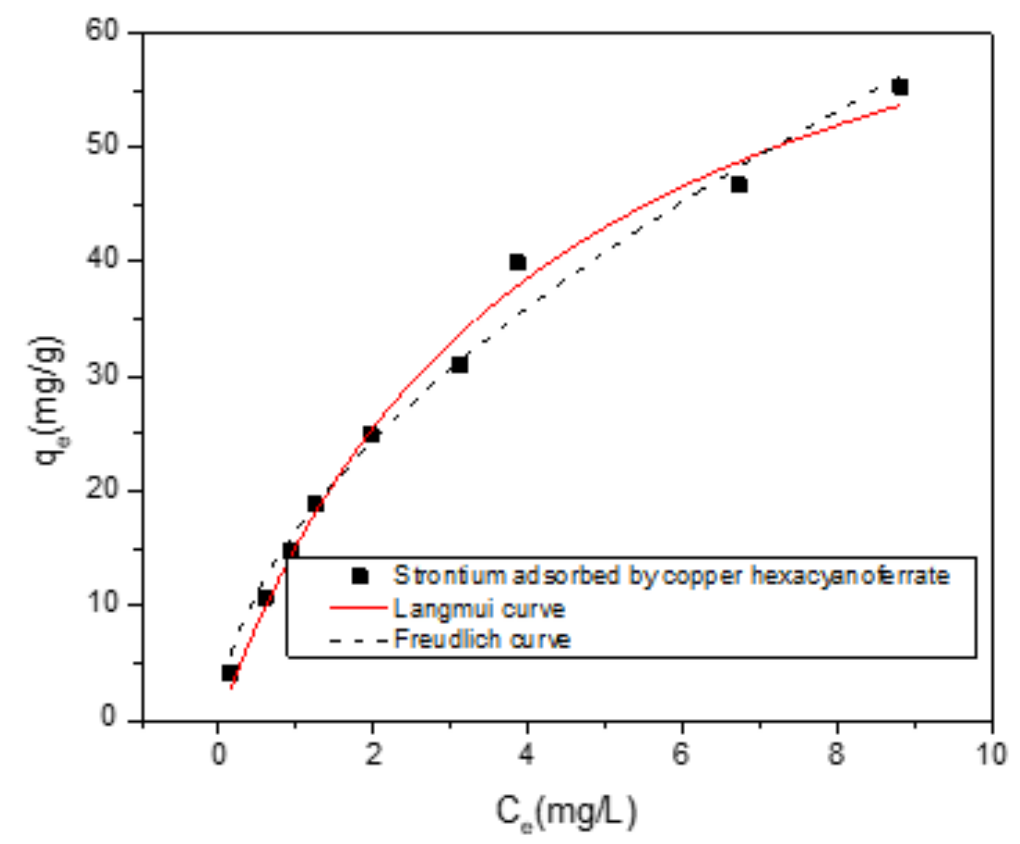

Figure 8. Langmuir and Freundlich isotherms for the adsorption of $\mathrm{Sr}^{2+}$ on $\mathrm{CuHF}$ 
Table 5. Langmuir and Freundlich isotherm parameters for $\mathrm{Cs}^{+}$and $\mathrm{Sr}^{2+}$ adsorption

\begin{tabular}{llll}
\hline Langmuir model & & & \\
\hline $\mathrm{Cs}^{+}$ & $\mathrm{Q}_{\mathrm{m}}(\mathrm{mg} / \mathrm{g})$ & $\mathrm{b}$ & $\mathrm{R}^{2}$ \\
\hline Freundlich model & 143.95 & 0.76 & 0.91 \\
\hline & & & \\
\hline $\mathrm{Cs}^{+}$ & $\mathrm{K}_{\mathrm{f}}(\mathrm{mg} / \mathrm{g})$ & $1 / \mathrm{n}$ & $\mathrm{R}^{2}$ \\
\hline Langmuir model & 87.14 & 0.12 & 0.81 \\
\hline & & & $\mathrm{R}^{2}$ \\
\hline $\mathrm{Sr}^{2+}$ & $\mathrm{Q}_{\mathrm{m}}(\mathrm{mg} / \mathrm{g})$ & $\mathrm{b}$ & 0.98 \\
\hline $\mathrm{Freundlich} \mathrm{model}$ & 79.26 & 0.24 & \\
\hline & & & $\mathrm{R}^{2}$ \\
\hline $\mathrm{Sr}^{2+}$ & $\mathrm{K}_{\mathrm{F}}(\mathrm{mg} / \mathrm{g})$ & $1 / \mathrm{n}$ & 0.98 \\
\hline
\end{tabular}

The correlation coefficients $\left(\mathrm{R}^{2}\right)$ of the Langmuir isotherms were 0.91 and 0.98 , while those of the Freundlich isotherm were 0.81 and 0.98 for cesium and strontium adsorbed by CuHF, respectively. The Langmuir model was conformable to describe the adsorption process of $\mathrm{Cs}^{+}$and $\mathrm{Sr}^{2+}$ by $\mathrm{CuHF}$ because the regression correlation coefficients were high. The maximum cesium adsorption capacity calculated according to the Langmuir model $\mathrm{Q}_{\max }=143.95 \mathrm{mg} / \mathrm{g}$ was equivalent to the experimental value of $143.33 \mathrm{mg} / \mathrm{g}$. In comparison, the strontium adsorbing capacity calculated according to the Langmuir model was higher than the experiment value.

The maximum adsorption capacities of various adsorbing materials for cesium and strontium are shown in Table 6. The copper hexacyanoferrate used in this study has a high uptake capacity for cesium compared to several other materials.

Table 6. The $\mathrm{Cs}^{+}$and $\mathrm{Sr}^{2+}$ adsorption capacities of various adsorbent materials

\begin{tabular}{lllll}
\hline Adsorbent & $\mathrm{pH}$ & $\begin{array}{l}\text { Maximum cesium } \\
\text { adsorption capacity } \\
\left(\mathrm{mg} \mathrm{g}^{-1}\right)\end{array}$ & $\begin{array}{l}\text { Maximum } \\
\text { strontium } \\
\text { adsorption } \\
\text { capacity }\left(\mathrm{mg} \mathrm{g}^{-1}\right)\end{array}$ & Reference \\
\hline Copper hexacyanoferrate & 6.0 & 143.95 & 79.26 & This study \\
MIL-101-SO3H & 6.0 & 36.47 & - & Aguila et al., 2016 \\
Zeolite & $2-10$ & 102 & 96.15 & Vipin et al., 2016 \\
Zeolite + MWCNT & $2-10$ & 113.6 & 107.5 & Vipin et al., 2016 \\
Zeolite A & $2-8$ & 207.47 & 303 & El-Kamash et al., 2008 \\
AC-PBNP & 6.8 & 36.1 & 9.26 & Ali et al., 2020 \\
\hline
\end{tabular}


Nguyen Dinh Trung, Le Vu Tram Anh, Truong Dong Phuong, Kieu Thi Dan Thy, Nguyen Tran Thuy Hong, Ning Ping, Duong Thi Huong Giang, and Ho Kim Dan

\section{Table 6. The $\mathrm{Cs}^{+}$and $\mathrm{Sr}^{2+}$ adsorption capacities of various adsorbent materials} (cont.)

\begin{tabular}{lllll}
\hline Adsorbent & $\mathrm{pH}$ & $\begin{array}{l}\text { Maximum cesium } \\
\text { adsorption capacity } \\
\left(\mathrm{mg} \mathrm{g}^{-1}\right)\end{array}$ & $\begin{array}{l}\text { Maximum } \\
\text { strontium } \\
\text { adsorption } \\
\text { capacity }\left(\mathrm{mg} \mathrm{g}^{-1}\right)\end{array}$ & Reference \\
\hline Nanozeolite composite & 7 & 208.38 & 97.08 & Faghihian et al., 2013 \\
Microzeolite composite & 7 & 160.01 & 78.90 & Faghihian et al., 2013 \\
\hline
\end{tabular}

\subsection{The adsorption time effect}

Adsorption kinetics is one of the critical factors that need to be considered for determining the efficiency of the adsorption process. Hence, in this study, the kinetics of cesium and strontium adsorption was analyzed to understand the adsorption behavior of $\mathrm{CuHF}$. Figure 9 shows the $\mathrm{Cs}^{+}$adsorption data by this adsorbent at $\mathrm{pH}=6$ for different time intervals. The adsorption was found to be time-dependent. The adsorption of $\mathrm{Cs}^{+}$ was rapid for the first 10 minutes, at which the removal rate reached $62 \%$. The adsorption equilibrium was approached after 18 minutes, and the removal of cesium ions from the experiment solution was $97.03 \%$.

The Hwang group found that the cesium uptake by $\mathrm{CuHF}$ reached equilibrium within 10 minutes (Hwang et al., 2017). Parajuli et al. (2016) suggested that the optimal pH is within the range of 4 to 8 and that the time needed to reach equilibrium is under 2 hours.

Strontium adsorption was also found to be time-dependent (Figure 10). The adsorption equilibrium was reached after 18 hours, and the strontium ion removal from the experiment solution was $71.29 \%$.



Figure 9. Sorption time of $\mathrm{Cs}^{+}$ions by $\mathrm{CuHF}$ 


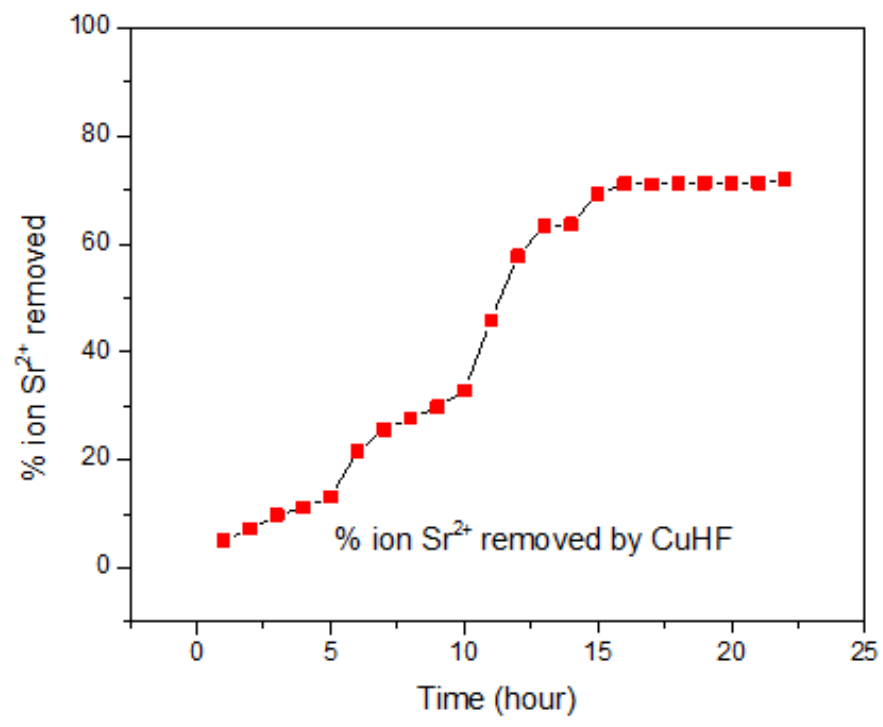

Figure 10. Sorption time of $\mathrm{Sr}^{2+}$ ions by $\mathrm{CuHF}$

\subsection{Cesium and strontium ion adsorption in competition with other constituent ions}

Several components may exist in radioactive wastewater that compete with cesium and strontium for adsorption sites or interact with themselves. $\mathrm{Ca}^{2+}, \mathrm{K}^{+}$, and $\mathrm{Na}^{+}$ ions were selected to test the effect of co-existing constituents.

Figure 11 shows that the co-existing ions, $\mathrm{Ca}^{2+}, \mathrm{Na}^{+}$, and $\mathrm{K}^{+}$, had little effect on cesium removal, and then only if they were in high concentration (over ten times higher than the cesium concentration). The effects of increased $\mathrm{Ca}^{2+}$ concentration levels at $\mathrm{pH}=6$ are illustrated in Figure 11 and show little adsorption competition. In high concentrations, calcium and potassium probably precipitated on the adsorbent surface and interfered with the $\mathrm{Cs}^{+}$adsorption process. $\mathrm{Na}^{+}$had little effect on the adsorbent performance in removing cesium.

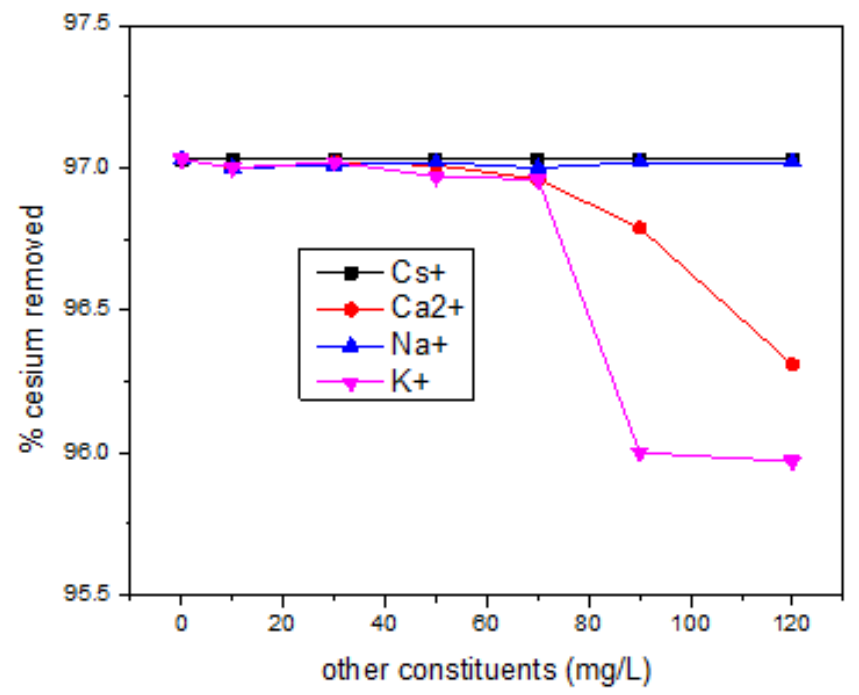

Figure 11. Constituent effect on the adsorption of $\mathrm{Cs}^{+}$by $\mathrm{CuHF}$ 
Figure 12 shows that the presence of co-existing ions, $\mathrm{Ca}^{2+}, \mathrm{Na}^{+}$, and $\mathrm{K}^{+}$, significantly decreased the strontium removal from $70 \%$ to $0 \%$ compared with the base. In all concentrations, the monovalent ions have a higher affinity for CuHF than the divalent ions in the adsorption process. Calcium ions showed a lower effect on strontium adsorption than potassium ions.

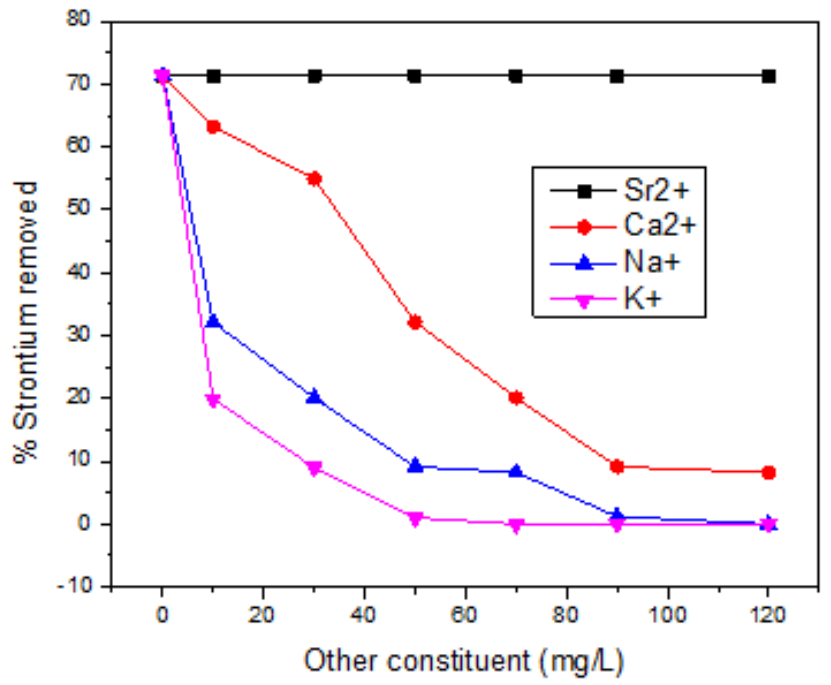

Figure 12. Constituent effect on the adsorption of $\mathrm{Sr}^{2+}$ by $\mathrm{CuHF}$

When studying the effects of other elements in the solution, the Gad group reported that sodium and calcium affect the adsorption of cesium by copper hexacyanoferrate (Gad et al., 2016). This study compares with the Gad group's results; the effect occurs only when the competing ion concentration is very high compared to the original cesium concentration. In the presence of $\mathrm{Ca}^{2+}$ and $\mathrm{K}^{+}$ions, the total amount of cesium adsorbed decreased by $3 \%$ compared to the base, but when the $\mathrm{Na}^{+}$ion is present in the solution, the amount of cesium adsorbed is not significantly reduced.

The above finding can be explained in terms of ionic radii. The radius of hydrated $\mathrm{K}^{+} \mathrm{M}^{+}\left(\mathrm{H}_{2} \mathrm{O}\right)_{\mathrm{n}}(3.31 \AA)$ is close to that of hydrated cesium (3.29 $\AA$ ); therefore, the $\mathrm{K}^{+}$ions can compete with the adsorption of cesium ions. In contrast, the radii of hydrated $\mathrm{Ca}^{2+}(4.12 \AA)$ and $\mathrm{Na}^{+}(3.58 \AA)$ are larger than that of the hydrated cesium ion; therefore, the $\mathrm{Ca}^{2+}$ and $\mathrm{Na}^{+}$ions cannot compete with the cesium ion adsorption.

From the research results discussed above, the $\mathrm{CuHF}$ has a high affinity for alkaline cations in the order: $\mathrm{Cs}^{+}>\mathrm{K}^{+}>\mathrm{Na}^{+}>\mathrm{Ca}^{2+}>\mathrm{Sr}^{2+}$.

\section{CONCLUSIONS}

A low-cost nanoscale copper hexacyanoferrate adsorbent for cesium $\left(\mathrm{Cs}^{+}\right)$ removal was prepared using the chemical co-precipitation method. The adsorbent, $\mathrm{Cu}_{13}\left[\mathrm{Fe}(\mathrm{CN})_{6}\right]_{14} \cdot(2 \mathrm{~K}) \cdot 10 \mathrm{H}_{2} \mathrm{O}$, has a cubic structure with the space group $\mathrm{F}-43 \mathrm{~m}$ in the range of 10-30 nm and a BET surface area of $462.42 \mathrm{~m}^{2} / \mathrm{g}$. The removal of $\mathrm{Cs}^{+}$and $\mathrm{Sr}^{2+}$ 
is dependent on $\mathrm{pH}$. The maximum adsorption capacity of the material is reached at $\mathrm{pH}=6$. The Langmuir model was conformable to describe the adsorption process of $\mathrm{Cs}^{+}$and $\mathrm{Sr}^{2+}$ by $\mathrm{CuHF}$ due to the high regression correlation coefficient. The maximum adsorption capacities calculated with the Langmuir model are $\mathrm{q}_{\max }=143.95 \mathrm{mg} / \mathrm{g}$ and $79.26 \mathrm{mg} / \mathrm{g}$ for $\mathrm{Cs}^{+}$and $\mathrm{Sr}^{2+}$, respectively. The adsorption of $\mathrm{Cs}^{+}$was rapid; after 18 minutes, $97.03 \%$ of the $\mathrm{Cs}^{+}$was removed from the experiment solution. In contrast, the adsorption of $\mathrm{Sr}^{2+}$ was slow; it took up to 18 hours for $71.29 \%$ of the strontium content to be removed from the solution.

The $\mathrm{Na}^{+}, \mathrm{Ca}^{2+}$, and $\mathrm{K}^{+}$ions in the solution affected the removal of $\mathrm{Cs}^{+}$only slightly, and only when present in high concentrations.

The monovalent ions have a higher affinity for the strontium ion than do the divalent ions in all concentrations. These results indicated that nanoscale $\mathrm{CuHF}$ is an attractive adsorbent for removing $\mathrm{Cs}^{+}$from aqueous radioactive wastewater.

\section{ACKNOWLEDGMENTS}

This study was supported by the Ministry of Education \& Training, Vietnam (No. B2020 DLA 01).

\section{REFERENCES}

Aguila, B., Banerjee, D., Nie, Z., Shin, Y., Ma, S., \& Thallapally, P. K. (2016). Selective removal of cesium and strontium using porous frameworks from high level nuclear waste. Chemical Communications, 52(35), 5940-5942.

Ali, M. M. S., Sami, N. M., \& El-Sayed, A. A. (2020). Removal of $\mathrm{Cs}^{+}, \mathrm{Sr}^{2+}$ and $\mathrm{Co}^{2+}$ by activated charcoal modified with Prussian blue nanoparticle (PBNP) from aqueous media: Kinetics and equilibrium studies. Journal of Radioanalytical and Nuclear Chemistry, 324(11), 189-201.

Ali, S. R., Bansal, V. K., Khan, A. A., Jain, S. K., \& Ansari, M. A. (2009). Growth of zinc hexacyanoferrate nanocubes and their potential as heterogeneous catalyst for solvent-free oxidation of benzyl alcohol. Journal of Molecular Catalysis A: Chemical, 303(1-2), 60-64.

Avila, M., Reguera, L., Rodríguez-Hernández, J., Balmaseda, J., \& Reguera, E. (2008). Porous framework of $\mathrm{T}_{2}\left[\mathrm{Fe}(\mathrm{CN})_{6}\right] \cdot \mathrm{xH}_{2} \mathrm{O}$ with $\mathrm{T}=\mathrm{Co}, \mathrm{Ni}, \mathrm{Cu}, \mathrm{Zn}$, and $\mathrm{H}_{2}$ storage. Journal of Solid State Chemistry, 181(11), 2899-2907.

Avramenko, V., Bratskaya, S., Zheleznov, V., Sheveleva, I., Voitenko, O., \& Sergienko, V. (2011). Colloid stable sorbents for cesium removal: Preparation and application of latex particles functionalized with transition metals ferrocyanides. Journal of Hazardous Materials, 186(2-3), 1343-1350.

Awual, M. R., Yaita, T., Taguchi, T., Shiwaku, H., Suzuki, S., \& Okamoto, Y. (2014). Selective cesium removal from radioactive liquid waste by crown ether 
immobilized new class conjugate adsorbent. Journal of Hazardous Materials, 278, 227-235.

Ayrault, S., Jimenez, B., Garnier, E., Fedoroff, M., Jones, D. J., \& Loos-Neskovic, C. (1998). Sorption mechanisms of cesium on $\mathrm{Cu}_{2}{ }_{2} \mathrm{Fe}^{\mathrm{II}}(\mathrm{CN})_{6}$ and $\mathrm{Cu}_{3}{ }_{3}\left[\mathrm{Fe}^{\mathrm{III}}(\mathrm{CN})_{6}\right]_{2}$ hexacyanoferrates and their relation to the crystalline structure. Journal of Solid State Chemistry, 141(2), 475-485.

Clarke, T. D., \& Wai, C. M. (1998). Selective removal of cesium from acid solutions with immobilized copper ferrocyanide. Analytical Chemistry, 70(17), 3708-3711.

El-Kamash, A. M. (2008). Evaluation of zeolite A for the sorptive removal of Cs+ and $\mathrm{Sr} 2+$ ions from aqueous solutions using batch and fixed bed column operations. Journal of Hazardous Materials, 151(2-3), 432-445.

Faghihian, H., Iravani, M., Moayed, M., \& Ghannadi-Maragheh, M. (2013). Preparation of a novel PAN-zeolite nanocomposite for removal of $\mathrm{Cs}^{+}$and $\mathrm{Sr}^{2+}$ from aqueous solutions: Kinetic, equilibrium, and thermodynamic studies. Chemical Engineering Journal, 222, 41-48.

Gad, H. M. H., Elsanafeny, H. A., Ali, M. M. S., Lasheen, Y. F., Abdelwahed, M. G. (2016). Factors affecting the sorption behavior of $\mathrm{Cs}^{+}$and $\mathrm{Sr}^{2+}$ using biosorbent material. Russian Journal of Applied Chemistry, 89, 988-999.

Haas, P. A. (1993). A review of information on ferrocyanide solids for removal of cesium from solutions. Separation Science and Technology, 28(17-18), 2479-2506.

Hwang, K. S., Park, C. W., Lee, K.-W., Park, S.-J., \& Yang, H.-M. (2017). Highly efficient removal of radioactive cesium by sodium-copper hexacyanoferratemodified magnetic nanoparticles. Colloids and Surfaces A: Physicochemical and Engineering Aspects, 516, 375-382.

Ishizaki, M., Akiba, S., Ohtani, A., Hoshi, Y., Ono, K., Matsuba, M., Togashi, T., Kananizuka, K., Sakamoto, M., Takahashi, A., Kawamoto, T., Tanaka, H., Watanabe, M., Arisaka, M., Nankawa, T., \& Kurihara, M. (2013). Protonexchange mechanism of specific $\mathrm{Cs}^{+}$adsorption via lattice defect sites of Prussian blue filled with coordination and crystallization water molecules. Dalton Transactions, 42(45), 16049-16055.

Işık, B., Kurtoğlu, A. E., Gürdağ, G., \& Keçeli, G. (2020). Radioactive cesium ion removal from wastewater using polymer metal oxide composites. Journal of Hazardous Materials, 403, 123652.

Ke, Y., Li, Y., Zhu, L., Zhou, Y., \& Liu, D. (2020). Rapid enrichment of cesium ions in aqueous solution by copper ferrocyanide powder. SN Applied Sciences, 2(4), 522.

Khandaker, S., Toyohara, Y., Kamida, S., \& Kuba, T. (2018). Adsorptive removal of cesium from aqueous solution using oxidized bamboo charcoal. Water Resources and Industry, 19, 35-46. 
Kido, G., Takasaki, M., Minami, K., Tanaka, H., Ogawa, H., Kawamoto, T., \& Yoshino, K. (2017). Analysis of Cs-adsorption behavior using a column filled with microcapsule beads of potassium copper hexacyanoferrate. Journal of Nuclear Science and Technology, 54(11), 1157-1162.

Kiener, J., Limousy, L., Jeguirim, M., Le Meins, J.-M., Hajjar-Garreau, S., Bigoin, G., \& Ghimbeu, C. M. (2019). Activated carbon/transition metal (Ni, In, Cu) hexacyanoferrate nanocomposites for cesium adsorption. Materials, 12(8), 1253.

Koo, Y.-H., Yang, Y.-S., \& Song, K.-W. (2014). Radioactivity release from the Fukushima accident and its consequences: A review. Progress in Nuclear Energy, 74, 61-70.

Loos-Neskovic, C., Ayrault, S., Badillo, V., Jimenez, B., Garnier, E., Fedoroff, M., Jones, D. J., \& Merinov, B. (2004). Structure of copper-potassium hexacyanoferrate (II) and sorption mechanisms of cesium. Journal of Solid State Chemistry, 177(6), 1817-1828.

Ma, B., Oh, S., Shin, W. S., \& Choi, S.-J. (2011). Removal of $\mathrm{Co}^{2+}, \mathrm{Sr}^{2+}$ and $\mathrm{Cs}^{+}$from aqueous solution by phosphate-modified montmorillonite (PMM). Desalination, 276(1-3), 336-346.

Mimura, H., Lehto, J., \& Harjula, R. (1997). Selective removal of cesium from simulated high-level liquid wastes by insoluble ferrocyanides. Journal of Nuclear Science and Technology, 34(6), 607-609.

Murray-Rust, P. (2021). Open-access collection of crystal structures of organic, inorganic, metal-organics compounds and minerals, excluding biopolymers. http://www.crystallography.net/cod/

Nakamoto, K. (1986). Infrared and Raman Spectra of Inorganic and Coordination Compounds. Wiley.

Nilchi, A., Saberi, R., Moradi, M., Azizpour, H., \& Zarghami, R. (2011). Adsorption of cesium on copper hexacyanoferrate-PAN composite ion exchanger from aqueous solution. Chemical Engineering Journal, 172(1), 572-580.

Parajuli, D., Takahashi, A., Noguchi, H., Kitajima, A., Tanaka, H., Takasaki, M., Yoshino, K., \& Kawamoto, T. (2016). Comparative study of the factors associated with the application of metal hexacyanoferrates for environmental Cs decontamination. Chemical Engineering Journal, 283, 1322-1328.

Rahman, R. O. A., Ibrahium, H. A., \& Hung, Y.-T. (2011). Liquid radioactive wastes treatment: A review. Water, 3(2), 551-565.

Shanker, U., Jassal, V., \& Rani, M. (2017). Degradation of toxic PAHs in water and soil using potassium zinc hexacyanoferrate nanocubes. Journal of Environmental Management, 204, 337-348.

Singh, S., Eapen, S., Thorat, V., Kaushik, C. P., Raj, K., \& D’Souza, S. F. (2008). Phytoremediation of ${ }^{137}$ cesium and ${ }^{90}$ strontium from solutions and low-level 
nuclear waste by Vetiveria zizanoides. Ecotoxicology and Environmental Safety, 69(2), 306-311.

Sun, S. D., Zhang, X. C., Cui, J., \& Liang S. H. (2020). Identification of the Miller indices of a crystallographic plane: A tutorial and comprehensive review on fundamental theory, universal methods based on different case studies and matters needing attention. RCS Nanoscale, 12(32), 16,657-16,677.

Takahashi, A., Kitajima, A., Parajuli, D., Hakuta, Y., Tanaka, H., Ohkoshi, S., \& Kawamoto, T. (2016). Radioactive cesium removal from ash-washing solution with high $\mathrm{pH}$ and high $\mathrm{K}^{+}$-concentration using potassium zinc hexacyanoferrate. Chemical Engineering Research and Design, 109, 513-518.

Todd, T. A., Batcheller, T. A., Law, J. D., \& Herbst, R. S. (2004). Cesium and strontium separation technologies literature review. United States. https://doi.org/10.2172/910643

Vincent, T., Vincent, C., \& Guibal, E. (2015). Immobilization of metal hexacyanoferrate ion-exchangers for the synthesis of metal ion sorbents-A minireview. Molecules, 20(11), 20,582-20,613.

Vipin, A. K., Ling, S., \& Fugetsu, B. (2014). Sodium cobalt hexacyanoferrate encapsulated in alginate vesicle with CNT for both cesium and strontium removal. Carbohydrate Polymers, 111, 477-484.

Vipin, A. K., Ling, S., \& Fugetsu, B. (2016). Removal of $\mathrm{Cs}^{+}$and $\mathrm{Sr}^{2+}$ from water using MWCNT reinforced Zeolite-A beads. Microporous and Mesoporous Materials, 224, 84-88.

Wang, L., Feng, M., Liu, C., Zhao, Y., Li, S., Wang, H., Yan, L., Tian, G., \& Li, S. (2009). Supporting of potassium copper hexacyanoferrate on porous activated carbon substrate for cesium separation. Separation Science and Technology, 44(16), 4023-4035.

Williams, A. N., Pack, M., \& Phongikaroon, S. (2015). Separation of strontium and cesium from ternary and quaternary lithium chloride-potassium chloride salts via melt crystallization. Nuclear Engineering and Technology, 47(7), 867-874.

$\mathrm{Xu}$, C., Wang, J., \& Chen, J. (2012). Solvent extraction of strontium and cesium: A review of recent progress. Solvent Extraction and Ion Exchange, 30(6), 623-650.

Yang, H., Sun, L., Zhai, J., Li, H., Zhao, Y., \& Yu, H. (2014). In situ controllable synthesis of magnetic Prussian blue/graphene oxide nanocomposites for removal of radioactive cesium in water. Journal of Materials Chemistry A, 2(2), 326-332.

Yasunari, T. J., Stohl, A., Hayano, R. S., Burkhart, J. F., Eckhardt, S., \& Yasunari, T. (2011). Cesium-137 deposition and contamination of Japanese soils due to the Fukushima nuclear accident. Proceedings of the National Academy of Sciences, 108(49), 19,530-19,534. 
Zong, Y., Zhang, Y., Lin, X., Ye, D., Qiao, D., \& Zeng, S. (2017). Correction: Facile synthesis of potassium copper ferrocyanide composite particles for selective cesium removal from wastewater in the batch and continuous processes. RSC Advances, 7(54), 33,974-33,974. 